\title{
Rapid culture test for adenovirus isolation
}

\author{
S. DAROUGAR, P. WALPITA, U. THAKER, N. VISWALINGAM, \\ AND M. S. WISHART
}

From the Institute of Ophthalmology, University of London, and Moorfields Eye Hospital, London

SUMmARY A rapid culture test has been developed and evaluated for the detection of adenovirus in ocular infections. The test requires only two days' incubation of the inoculated cell monolayers on coverslips in flat bottomed tubes followed by detection of adenovirus inclusions using immunofluorescence staining method. The sensitivity of the rapid test is found to be comparable with that of the conventional tissue culture test which depends on the development of a cytopathic effect requiring 2-21 days' incubation (mean 9.4, SD 4.9).

Adenovirus ocular infections eccur sporadically throughout the year, and outbreaks are frequent both in the community and in hospitals and other institutions. ${ }^{1-4}$ In most cases of adenovirus ocular infections, particularly at an early stage, differential diagnosis from other viral, bacterial, and chlamydial infections, and acute allergic conditions is difficult on clinical grounds alone.

Several laboratory tests are available for the diagnosis of adenovirus ocular infections. Direct demonstration of the agent in exfoliated cells ${ }^{5-7}$ is rapid and sensitive but requires high quality smears and strict criteria for identification of viral inclusions. Sensitive serological methods for the detection of adenovirus antibodies are available but require at least two specimens collected 7-10 days apart to show a rise in titre. Isolation of the virus in tissue culture, which relies on the development of cytopathic effect and subsequent identification of virus, is sensitive for the diagnosis of adenovirus ocular infection. However, the major disadvantage of this method is that it may require up to 21 days' incubation period. Results are therefore usually not available to the physician in time to influence his management decisions.

We present here the development of a rapid, simple, and sensitive tissue culture test for the diagnosis of ocular adenovirus infection.

\section{Materials and methods}

SPECIMENS

Conjunctival specimens were collected from patients

Correspondence to Professor S. Darougar. Institute of Ophthalmology. Judd Strect, London WC1H 9QS. presenting with conjunctivitis to the External Eye Disease Clinic at Moorfields Eye Hospital, London. Laboratory strains used were isolated in our laboratory from patients with ocular adenoviral infections.

Conjunctival swabs were collected and placed in 2SP transport medium with antibiotics ${ }^{*}$ with the addition of $3 \% \mathrm{v} / \mathrm{v}$ fetal bovine serum. All clinical specimens were stored in liquid nitrogen $\left(-180^{\circ} \mathrm{C}\right)$ for transport to the laboratory where they were stored at $-70^{\circ} \mathrm{C}$ until cultured.

\section{TISSUE CULTURE AND INOCULATION}

HEp2 cells were seeded at the rate of 25000 to 30000 per $\mathrm{ml}$ of growth medium into tissue culture testtubes (TT) and in flat bottomed tubes (FBT) containing a $13 \mathrm{~mm}$ diameter coverslip (E5/R Redhill Surgical Co. Ltd., Glasgow). Growth medium consisted of Eagle's minimum essential medium supplemented with vitamins, glutamine, $10 \%$ fetal bovine serum, and antibiotics (vancomycin $100 \mu \mathrm{g} / \mathrm{ml}$ and streptomycin $50 \mu \mathrm{g} / \mathrm{ml})$. The seeded TT and FBT were incubated at $35^{\circ} \mathrm{C}$ for 48 hours. At the end of this period growth medium was replaced with maintenance medium (same as growth medium but with only $3 \%$ fetal bovine serum).

Equal volumes of samples of laboratory or clinical material were inoculated each into one TT and one FBT containing cell monolayers. Positive and negative controls were always included in each batch of tests.

CONVENTIONAL TISSUE CULTURE TEST

The inoculated TTs were rolled at $35^{\circ} \mathrm{C}$ and examined on alternate days for cytopathic effect (CPE). Smears 
Fig. 1 Bright particulate intracellular adenovirus inclusions. $(\times 532)$.

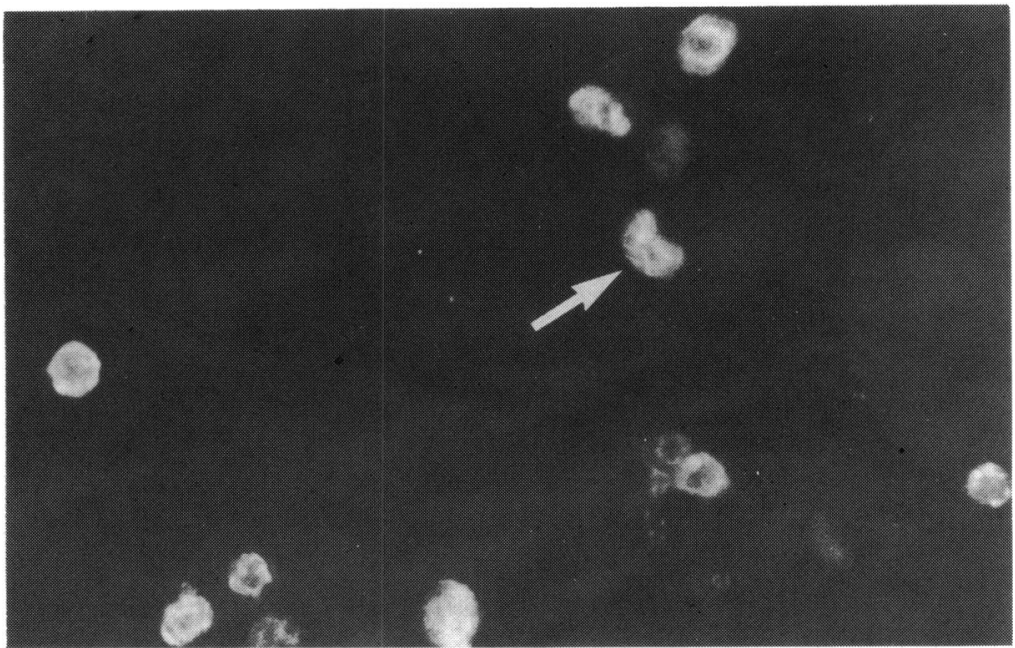

were made from tubes showing CPE and the virus identified by an indirect immunofluorescence method. The individual steps involved in the test are shown in Table 1.

\section{RAPID CULTURE TEST}

The inoculated FBTs were incubated at $35^{\circ} \mathrm{C}$ for 48 hours. At the end of this period the coverslips were fixed in methanol for 10 minutes at room temperature, and stained by immunofluorescence (IF) method. The individual steps involved in the rapid test are shown in Table 1.

\section{IMMUNOFLUORESCENCE STAINING METHOD}

Group specific horse antiadenovirus antiserum and antihorse IgG conjugated with fluorescein isothiocyanate (Wellcome Reagents Ltd.) were used for staining the adenovirus. All batches of sera and conjugates were previously titrated to determine their optimum working dilutions.

Coverslips mounted on staining frames were covered with the antiadenovirus serum and incubated in a humid chamber for half an hour at $35^{\circ} \mathrm{C}$. They were then thoroughly washed for 15 minutes in phosphate buffered saline at $\mathrm{pH} 7 \cdot 3$ by means of a magnetic stirrer. They were air dried and then covered with the fluorescein conjugated antiserum. Incubation and washing was repeated as before, except for an extra final wash of the coverslips in distilled water for five minutes, before being dried and mounted in buffered glycerol. The coverslips were examined with a Zeiss standard 18UV microscope fitted with a Zeiss filter set IO. Low power $(\times 160)$ magnification was used to locate the inclusions, and the quality of the inclusions was checked under high power $(\times 400)$ magnification.

The criteria of positivity by this method during the course of this study was the detection of at least two brightly fluorescent particulate inclusions within intact cells (Fig. 1).

\section{EFFECTS OF CENTRIFUGATION}

To investigate the effect of high speed centrifugation on adenovirus isolation rate clinical and laboratory specimens were divided equally into two FBTs. One FBT was centrifuged at $15000 \mathrm{~g}$ for one hour before incubating, and the other was incubated without centrifugation.

\section{Results}

Aliquots of 1038 clinical specimens and 58 laboratory strains were inoculated in parallel by the rapid culture

Table 1 Comparison of the steps involved in the rapid culture test and the conventional tissue culture test

\begin{tabular}{|c|c|}
\hline Rapid culture test & $\begin{array}{l}\text { Conventional tissue culture } \\
\text { test }\end{array}$ \\
\hline $\begin{array}{l}\text { 1. Cell monolayer on coverslip in FBT } \\
\text { 2. Inoculation } \\
\text { 3. Incubation-2 days } \\
\text { 4. IF staining } \\
\text { Course of test }-2 \text { days }\end{array}$ & $\begin{array}{l}\text { Initial inoculation } \\
\text { Cell monolayers in TT } \\
\text { Inoculation } \\
\text { Incubation-7 days } \\
\text { Examination for CPE } \\
\text { Ist pass } \\
\text { Incubation-7 days } \\
\text { Examination for CPE } \\
\text { 2nd pass } \\
\text { Incubation-7 days } \\
\text { Examinc for CPE } \\
\text { IF staining of smears from } \\
\text { test tubes showing CPE } \\
\text { Course of test-up to } 21 \\
\text { days }\end{array}$ \\
\hline
\end{tabular}


Table 2 Comparative sensitivity of the rapid culture test and the conventional tissue culture test

\begin{tabular}{lccc}
\hline Specimens & $\begin{array}{l}\text { Nos. } \\
\text { inoculated }\end{array}$ & Nos. positive & \\
\cline { 3 - 4 } & & Rapid (\%) test & $\begin{array}{l}\text { Conventional (\%) } \\
\text { test }\end{array}$ \\
\hline $\begin{array}{l}\text { Clinical } \\
\text { Laboratory }\end{array}$ & 1038 & $116(11 \cdot 2)^{*}$ & $113(10 \cdot 8)^{*}$ \\
strains & 58 & $44(75 \cdot 9) \dagger$ & $47(81 \cdot(0) \dagger$ \\
& & &
\end{tabular}

${ }^{*}$ The difference not statistically significant $\left(\chi^{2}=0 \cdot(02, p=0 \cdot 9)\right.$.

$\dagger$ The difference not statistically significant $\left(\chi^{2}=0 \cdot 2, p=0 \cdot 65\right)$.

Table 3 Correlation of positivity by the rapid culture test and the conventional tissue culture test using clinical specimens

\begin{tabular}{llc}
\hline Positive & \multicolumn{2}{l}{$\begin{array}{l}\text { Specimens positive for } \\
\text { adenovirus isolation }\end{array}$} \\
\cline { 2 - 3 } & No. & $\%$ \\
\hline Rapid culture test and standard & 89 & $63 \cdot 5$ \\
$\quad$ culture test & 27 & $19 \cdot 3$ \\
Rapid culture test only & 24 & $17 \cdot 1$ \\
Conventional tissuc culture test only & 140 & \\
Total & & \\
\hline
\end{tabular}

Table 4 Day of first appearance of cytopathic effect in 113 positives in the conventional tissue culture test

\begin{tabular}{lll}
\hline Days & Nos. showing CPE* & $\%$ \\
\hline At 2 days & 12 & $10 \cdot 6$ \\
At 3-7 days & 39 & $34 \cdot 5$ \\
At 8-14 days & 43 & $38 \cdot 1$ \\
At 15-21 days & 19 & $16 \cdot 8$ \\
\hline
\end{tabular}

${ }^{*}$ Mcan days for CPE 9.4, SD 4.9.

test and the conventional tissue culture test. The overall rates of adenovirus isolation by the two culture tests were similar (Table 2). Correlation of positivity between the two methods is shown in Table 3.

Table 4 shows the number of days taken for the development of CPE in the conventional tissue culture test. At two days approximately $10 \%$ of the 113 adenovirus positive cultures showed CPE, and even at seven days only $45 \%$ of the specimens had become positive (Table 4). The mean time taken to develop CPE was $9 \cdot 4$ days, SD $4 \cdot 9$.

\section{EFFECTS OF CENTRIFUGATION}

To study the effects of high speed centrifugation on adenovirus detection rate 72 specimens ( 33 clinical isolates and 39 laboratory specimens) were inoculated in duplicate. Adenovirus was detected in 54 of the centrifuged FBTs and in 51 of the non-centrifuged ones. This difference is not statistically significant $\left(\chi^{2}=0 \cdot 8, p=0 \cdot 36\right)$.

\section{Discussion}

We have developed and evaluated a rapid culture test for the detection of adenovirus in clinical material. The test requires only two days to complete and has a sensitivity comparable with that of the conventional tissue culture method. The test involves far fewer steps for the detection and identification of the virus than the conventional test (Table 1) and hence is considerably cheaper.

Human embryonic kidney (HEK) cells have been shown to be highly sensitive for the isolation of ocular adenovirus." In a preliminary study we compared the sensitivity of this cell line with that of HEp2 cells used in this investigation. Adenovirus isolation rate in the two-cell systems did not vary significantly, although the development of cytopathic effect was marginally quicker in the HEK cells (unpublished observations).

In a pilot study using clinical specimens and laboratory strains we compared the sensitivity of the rapid culture test following 24,48 , and 72 hours incubation. The adenovirus detection rate at 24 and 48 hours was $20.5 \%$ and $52.5 \%$ respectively, whereas the detection rate at 48 and 72 hours was closely comparable. Hence, a 48-hours incubation period was considered as optimum in the rapid culture test.

In our hands the indirect IF staining method has been satisfactory for the detection of adenovirus inclusions. The distinction between positive and negative results was clear-cut. The positive reaction produced bright fluorescent green, particulate, intracellular inclusions, with minimal background staining (Fig. 1). For IF staining the reagents should be highly specific, and each batch should be titrated before use for maximum sensitivity and minimum background. Positive and negative controls should be carried with each batch of tests to control the quality of tissue culture and staining. In a pilot study we found that the direct IF staining method is also satisfactory and could reduce the staining time by approximately half. However, higher-titre group-specific antiadenovirus antibody is necessary for direct staining.

In this study we set criteria of positivity requiring identification of at least two brightly fluorescent, particulate intracellular inclusions by the rapid culture test. However, during the course of this study in five cases we found only one inclusion in the rapid culture test. Of these, two were also positive for adenovirus by the conventional tissue culture method. Furthermore, such inclusions were never found in negative controls. This leads us to believe that the presence of even one well defined inclusion is adequate for the diagnosis of adenovirus by the rapid culture test.

In spite of good overall correlation between the positivity rates of the rapid and standard culture test it was found that about $36 \%$ of the clinical specimens 
were positive in only one of the two tests (Table 3 ). This may be due to the possibility that very little infective material was present in these specimens. This was confirmed by our findings that, in general, most of the discrepant results were associated either with the presence of a few inclusions in rapid culture test or a small amount of CPE following a long incubation period in the conventional tissue culture test.

The effects of centrifugation have been found to be beneficial for the growth of chlamydiae $1 "$ and some viruses $^{11} 12$ in tissue culture. In this study centrifugation at $15000 \mathrm{~g}$ appeared to have no significant effect in improving the isolation rate of adenovirus from ocular specimens.

The new culture test is much simpler, cheaper, and faster than the conventional tissue culture test but as sensitive as that test for the detection of adenovirus from ocular infections. The rapidity of the method means that the results may be available in two days instead of up to three weeks taken by the conventional method. Hence this rapid culture test can become a valuable tool in the diagnosis and management of adenovirus ocular infections.

\section{References}

1 Darougar S, Walpita P, Thaker U, Viswalingam N, Gardner L. McSwiggan DA. Adenovirus serotypes isolated from ocular infections in London. Br J Ophthalmol 1983; 67: 111-4.

2 Davidson SI. Epidemic keratoconjunctivitis-a report of an outbreak which resulted in ward cross infection. BrJ Ophthalmol 1964: 48: 573-80.

3 Liabson PR. Ortolan G. Drupre-Strachan S. Community and hospital outbreaks of epidemic keratoconjunctivitis. Arch Ophthalmol 1968; 80: 467-73.

4 Kendall EJC, Riddle RW, Tuck HA, Rodan KS, Andrews BE. McDonald JC. Pharyngoconjunctival fever: school outbreaks in England during the summer of 1955 associated with adenovirus types 3, 7 and 14. Br Med J 1957; ii: 131-6.

5 Gardner PS. McQuillan J. Black MM. Richardson J. Rapid diagnosis of herpes virus hominis infection in superficial lesions by immunofluorescent antibody techniques. Br Med J 1968: iv: $89-92$.

6 Chien Liu, Llanes-Rodas R. Application of immunofluorescent technique to the study of pathogenesis and rapid diagnosis of viral infections. Am J Clin Pathol 1972; 57: 829-34.

7 Schwartz HS, Vastine DW, Yamashioya H, West CE. Immunofluorescent detection of adenovirus antigen in epidemic keratoconjunctivitis. Invest Ophthalmol Visual Sci 1976; 15: 199-207.

8 Gordon FB, Harper IA, Quan AL, Treharne JD. Dwyer R StC. Garland JA. Detections of Chlamydia (bedsonia) in certain infections of man. 1. Laboratory procedures: comparison of yolk sac and cell culture detection for detection and isolation. $J$ Infect Dis 1969; 120: 451-62.

9 McSwiggan DA. Darougar S. Rahman AFMS, Gibson JA. Comparison of the sensitivity of human embryo kidney cells. HeLa cells and W138 cells for the primary isolation of viruses from the cye. J (lin Pathol 1975; 28: 410-3.

10) Darougar S, Cubitt S. Jones BR. Effect of high speed centrifugation on the sensitivity of irradiated McCoy cell culture for the isolation of chlamydia. BrJ Vener Dis 1974; 50: 308-12.

11 Osbourne JE, Waller DL. Enhancement of infectivity of murine cytomegalovirus in vitro by centrifugal inoculation. J Virol 1968: 2: $386-90$.

12 Darougar S, Gibson JA. Thaker U. Effect of centrifugation on herpes simplex virus isolation. J Med Virol 1981; 8: 231-5. 